\title{
Opportunities for large-scale energy storage in geological formations in mainland Portugal
}

\author{
Júlio F. Carneiro ${ }^{\mathrm{a}, *}$, Catarina R. Matos ${ }^{\mathrm{a}, \mathrm{b}}$, Serge van Gessel $^{\mathrm{c}}$ \\ a ICT - Instituto de Ciências da Terra, Universidade de Évora, Évora, Portugal \\ b Programa Doutoral MIT Portugal, Universidade de Coimbra, Coimbra, Portugal \\ ${ }^{c}$ TNO, Princetonlaan 6, Utrecht, NL-3584 CB, the Netherlands
}

\section{A R T I C L E I N F O}

\section{Keywords:}

Energy storage

Renewable Energy Sources

Geological reservoirs

Portugal

\begin{abstract}
A B S T R A C T
This article presents the methodology and results of the first screening conducted in Portugal to identify geological formations suitable for large-scale storage of energy from renewable sources. The screening focused on the identification of adequate porous media rocks, salt formations and igneous host rocks that could act as reservoirs for gas (hydrogen or methane) storage, Compressed Air Energy Storage, Underground Pumped Hydro and Underground Thermal Energy Storage.

Public access geological information was collected, compiled in a database and spatially referenced in a GIS environment. The GIS and database were cross-checked with criteria for selecting geological reservoirs and with existing or anticipated spatial, environmental and social constraints. In a third step the feasibility of deploying each large-scale energy storage technology in each prospective reservoir was assessed and classified according to confidence, ranging from unlikely to proven, and to proximity to areas with wind or solar energy potential, accessibility to power transmission lines and natural gas networks.

The outcome is a first screening of priority sites to be studied at the local scale in future projects. Early target for detailed studies are the existing salt caverns and an abandoned salt mine in the Lusitanian Basin. Natural gas storage in salt formations is being carried in the region for decades, proving the adequacy of the salt formations and demonstrating the social acceptance. Porous media aquifers in the same Lusitanian basin may also hold an interesting potential, although there is considerable uncertainty due to the scarcity of geological data about deep aquifers. The Sines industrial cluster, in SW Portugal, is another interesting target area, due to the existence of a host rock with proven containment capacity.

The technologies with the best potential for application in the Portuguese geologic context seem to be CAES and Underground Gas Storage linked to Power-to-gas projects.
\end{abstract}

\section{Introduction}

Energy storage is essential for the integration of intermittent and non-dispatchable renewable energy sources (RES) and for the management of fossil fuel power plants in a smart grid context [1]. Energy Storage systems can broadly be classified in small-scale and large-scale systems, based on the discharge times and power capacities (Fig. 1). Large-scale energy storage systems have a power capacity of tens to hundreds of MW and aim at long term storage purposes.

Large-scale energy storage is the best solution to provide a better management of the grid, ensure energy security, balance supply and demand and to convergence towards a low carbon economy, and includes benefits like reliability, power quality, transmission optimization, black-start functions and arbitrage for utility companies $[13,18]$.
The need for these large scale systems becomes evident when looking at the projections of the European Energy Storage Association which estimates that storage demand at EU level in 2050 will range from 70 to $220 \mathrm{GW}$ (compared to $45 \mathrm{GW}$ existing today) and an energy storage capacity of 1500-5500 GW h [17]. Previously, the International Energy Agency [18] estimated that limiting global warming to below $2{ }^{\circ} \mathrm{C}$ will necessitate globally installed energy storage capacity to increase from $140 \mathrm{GW}$ in 2014 to $450 \mathrm{GW}$ in 2050 .

In recent years, underground space has been increasingly seen as a potential reservoir for storage of energy carriers. The use of porous media and salt caverns for storing natural gas is implemented in several countries, but storage of $\mathrm{CO}_{2}$, heat, hydrogen and other energy carriers have drawn awareness to the large storage space available in rock formations, while minimising environmental and social impacts, and

\footnotetext{
* Corresponding author.

E-mail address: jcarneiro@uevora.pt (J.F. Carneiro).
} 


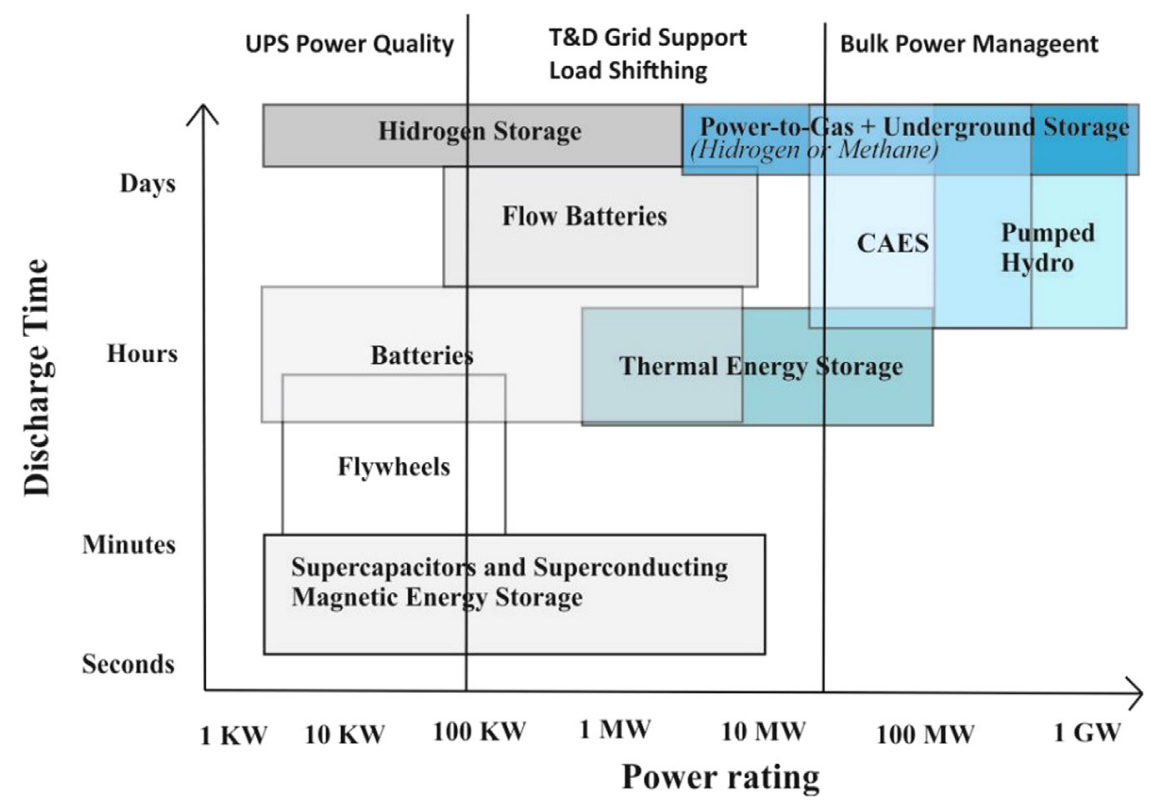

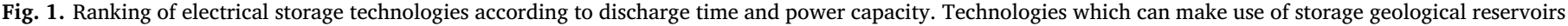
are marked in bluish. Adapted from Aneke and Wang [33].

decreasing the need for surface space [2-4].

Moreover, underground reservoirs increase the security of storing inflammable gases and can provide an economic value to the pore space of depleted hydrocarbon reservoirs, non-potable aquifers, and abandoned tunnels and mines. Still, proper selection and characterisation of geological reservoirs is essential to decrease risks and impacts (e.g. induced seismicity, contamination of freshwater aquifers, loss of fluid, etc) resulting from the injection of a fluid in a geologic formation.

Geological storage of energy can be accomplished by injection of compressed air (compressed air energy storage - CAES), water (underground pumped hydroenergy storage - UPHES), gas (methane or hydrogen - underground gas storage - UGS) or heat (underground thermal energy storage-UTES) in porous rocks or engineered rock caverns. These technologies are at very different Technology Readiness Levels, some being already commercially implemented for decades (such as CAES and UTES) while others are almost conceptual (UPHES).

A CAES facility stores mechanical energy by using electricity to compress air and inject it in a geologic formation. When electricity is required, the pressurized air is expanded in a turbine, driving a generator for power production (Fig. 2a) [5-8]. There are two commercial CAES plants in the world, the 290 MW Huntorf plant in Germany, operational since 1978, and the $110 \mathrm{MW}$ McIntosh plant in USA, which started operations in 1991 [1,7,9]. Both facilities resort to storage in salt caverns and use natural gas to heat-up the expanding air stream (Diabatic CAES), but the quest for higher efficiencies has led to research in technology variants in which the heat of compression is stored separately and fed back into the compressed air upon expansion (Adiabatic CAES).

UGS relies on a Power-to-Gas process in which surplus renewable energy is used to produce a gas fuel (e.g. hydrogen, methane) which is injected in a geologic reservoir and used to generate electricity when in peak demand (Fig. 2b). This technology benefits from the wide experience with storing natural gas in geological formations, a mature technology implemented on many locations worldwide [5]. However, there are only three hydrogen storage facilities, two of which are in the USA, and another one in UK, all in salt caverns [10].

UHPS is an adaptation of the conventional Pumped Hydro Energy Storage, conceived to eliminate dependency of the latter upon topography, provide higher hydraulic heads and reduce environmental concerns (Fig. 2d). In UPHS the lower water reservoir is underground, in a cavern $[1,4,11]$. The gravitational energy is established by elevation differences between the surface and the underground water reservoirs [5]. There are currently no operational UPHS facilities.

UTES in geological formations is accomplished by injecting and subsequently extracting hot/cold water from a geologic reservoir using one or more wells, coupled through hydraulic pumps and heat exchangers (Fig. 2c), providing seasonal storage of heat in underground reservoirs [12-15]. The geological reservoir can be a porous media (aquifer thermal energy storage), an engineered cavern (Rock Cavern Thermal Energy Storage), such as the use of a mine in the southern part of the Netherlands, where a low temperature district heating system is operational since 2008 [16], or a set of boreholes coupled with heat exhangers (Borehole Thermal Energy Storage). The latter is generally of smaller-scale than the other UTES systems and is not further addresses in this article.

The need for development of business models, demonstration and pilot programmes in large scale storage particularly related to P2G, hydrogen and CAES has been recommended by several bodies ([19] \{[19], 2013 \#772).

In Europe several countries have already started planning their energy policy considering the large storage capacity provided by geological reservoirs. The Netherlands are studying the use of underground gas storage to replace the swing capacity of natural gas fields, while Germany launched three geoscientific research projects working on geological storage options - ANGUS + , InSPEE, H2STORE \{[21], 2017 \#757\}. In the UK several Projects of Common Interest, funded at EU level, have been proposed to study the possibility of CAES in multiple locations in the UK [20]. Several other European contries are active in this domain, with the Czech republic testing the storage of thermal energy in rock massifs and abandoned mines, and Ireland and Switzerland planning the implementation or conducting pilot projects on CAES.

Recently the European Union, in the scope of Horizon 2020, commissioned the mapping of the large-scale energy storage capacity in the EU Member States- the EASTMAP project [5]. ESTMAP regarded energy storage in a broad context and covered gas-, heat- and electricity-related services, as well as various carriers used to capture and transport energy (e.g. hydrogen, compressed air, etc.). The project was conducted by a consortium composed of TNO, BRGM, ECOFYS and VITO, but other entities were subcontracted for data collection and treatment in 
a)

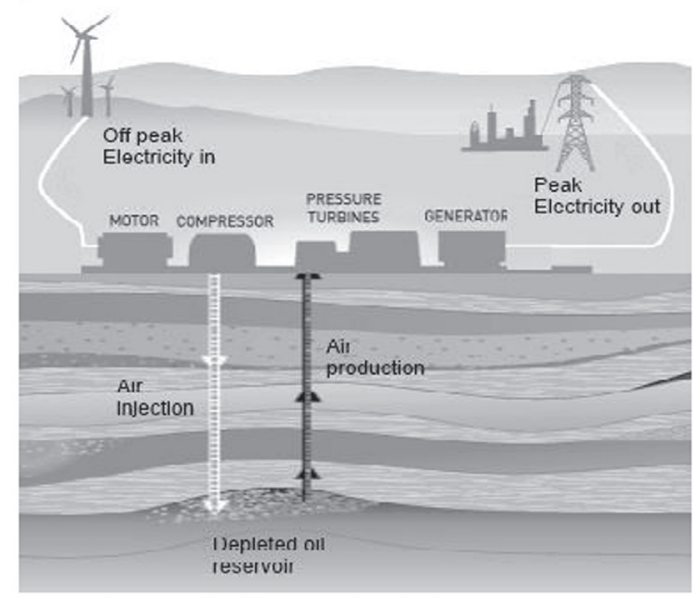

c)

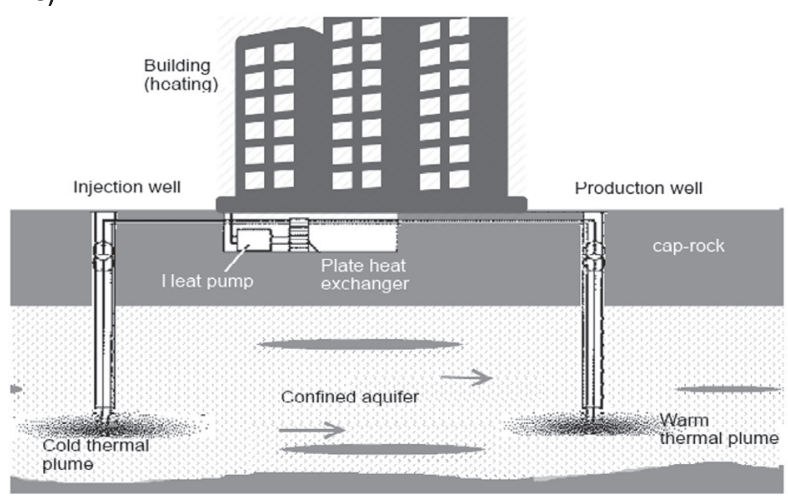

b) elr pectricity in

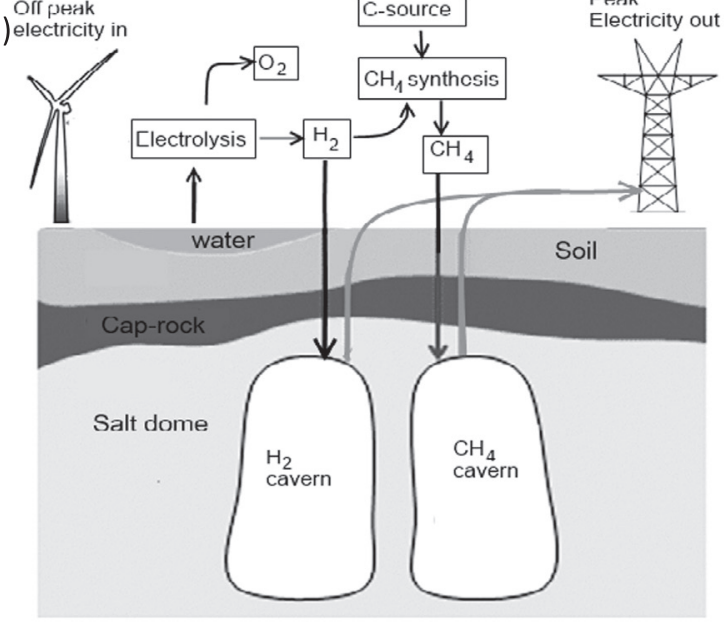

d)

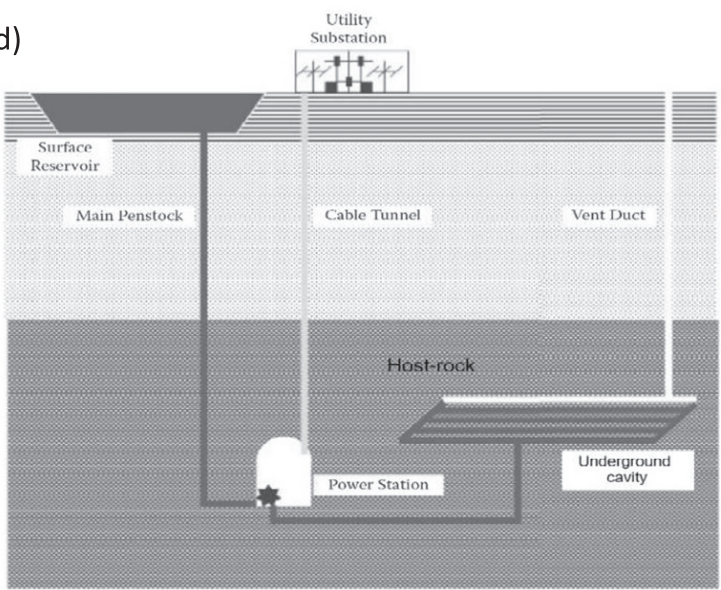

Fig. 2. Schematic representation of large-scale energy storage technologies and main geological reservoir types.; a) Compressed Air Energy Storage (CAES), with surplus electricity being used to compressed air and inject it in a depleted oil reservoir. During peak demand, air is produced, heated and expands to generate electricity; b) Underground Gas Storage (UGS), connected to a power-to-gas process with hydrogen or methane being produced and stored in salt caverns; c) Underground Thermal Energy Storage (UTES) in winter configuration, extracting groundwater previously injected in an aquifer to heat the building resorting to heat exhangers. In summer configuration the flow direction is reversed and the building is cooled; d) Underground Pumped Hydro Storage (UPHS), with the lower reservoir and power station in engineered rock caverns in a host-rock. The figure also represents the main geological reservoir types. Notice that each storage technology may be applied in different reservoir types, see Table 5 for feasibility and maturity of each storage technology for the different reservoir types. Adapted from $\{$ Barnes [1] \#766\}\{[34] \#655\}.

each of the EU Member States.

This article presents the results of the mapping conducted in Portugal and addresses the identification of the geological formations suitable for energy storage and the match between reservoir types and energy storage technologies.

\section{Methodology}

The distinction between use of the porous space and use of caverns, provides the main difference between geological formations targeted formationstageted for energy storage (Fig. 2):

- Porous media reservoirs, in which storage of energy is achieved by filling the pores in the rock media with an energy carrier injected in the reservoir through wells. Production of energy takes place by recovering the fluid through the same or other wells. Saline aquifers and depleted hydrocarbon reservoirs in sedimentary rocks, such as sandstones, limestones, conglomerates, etc..., are typically the target formations, due to the high porosity (to provide the storage capacity) and permeability (to ensure injectivity and productivity);

- Engineered caverns, in which the energy carrier is stored in an underground cavity with a well-defined geometry, usually spread over an area of a few thousand of $\mathrm{m}^{2}$. Engineered caverns require low porosity and low permeability rocks to ensure that the stored fluid does not migrate to the surrounding formation. Caverns created by solution-mining of salt rocks are the most common - there is a vast experience in natural gas storage in salt rocks. Caverns may also be created through excavation of host-rocks, a term referring to low porosity / low permeability hard-rocks, such as granites or basalts, or soft-rocks such as shales or unfractured limestones. Caverns in abandoned mines can be used, especially if combined with the use of linings to ensure containment of the fluids and allow for higher storage pressure (LRC - Lined Rock Caverns).

The reservoir types considered in this work were salt rock formations (bedded salt and salt domes), saline aquifers, igneous host-rocks and existing or planned caverns with well-defined geometries. Depleted hydrocarbon fields do not exist in Portugal and abandoned mines were not considered except for salt mines.

Fig. 3 depicts the workflow to select the reservoirs and their match with the storage technologies. In a first step, the identification and mapping of the potential reservoirs relied on public access information collected from geological surveys, geological maps, scientific publications, drilling records and borehole logs, as well as data supplied by the 


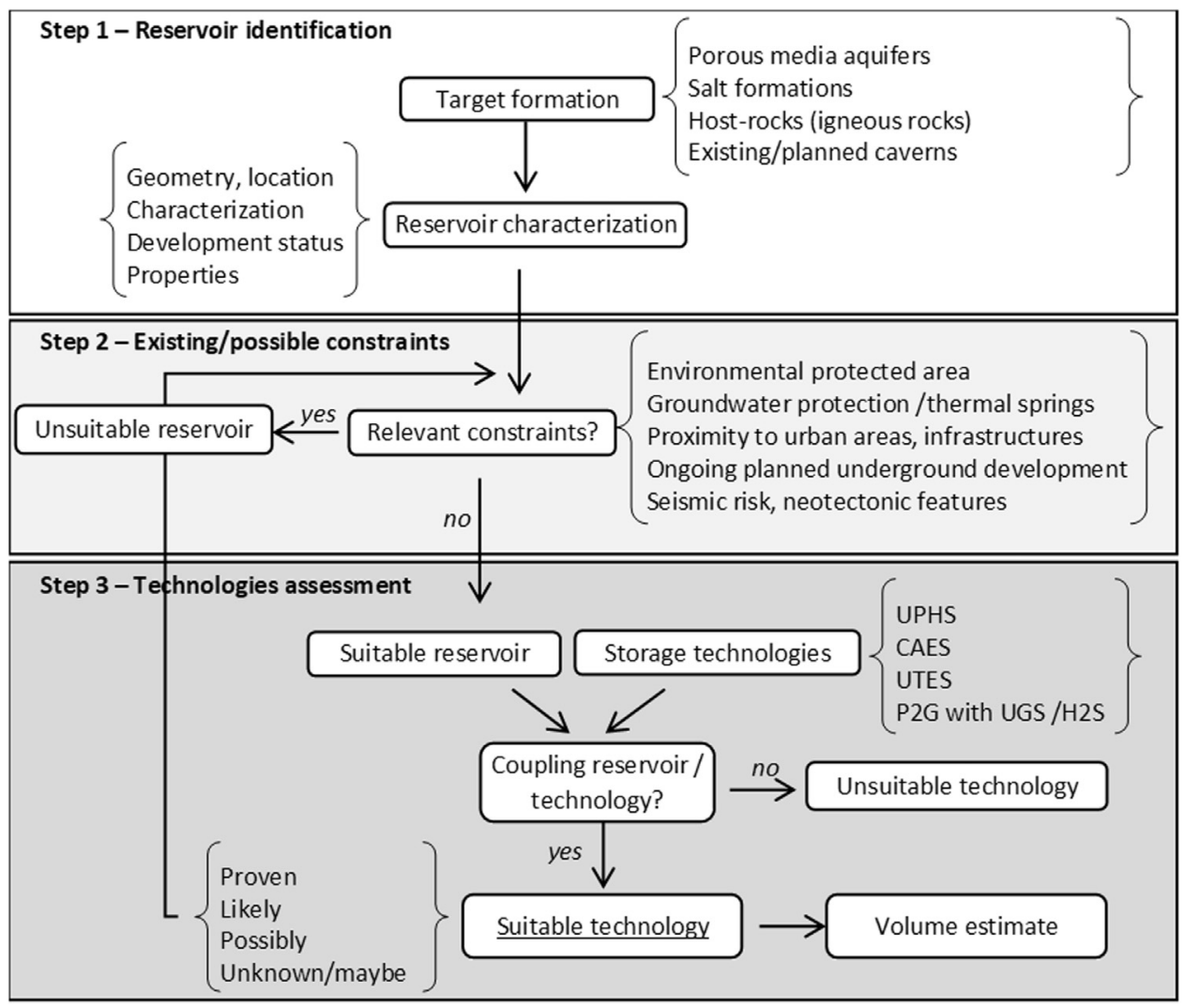

Fig. 3. Workflow for reservoir selection and assessment of technologies suitable for each reservoir. Step 1 relies on the collection of public access data on the geological formations, their features and on the integarion in a GIS environment; step 2 uses the GIS to identify the relevant constraints for each possible reservoir in step 2; step 3 assesses the feasibility of applying each energy storage technology individually at each reservoir selected in step 2 .

Table 1

List of Geographical Information System dataset and attributes considered for reservoir identification.

\begin{tabular}{|c|c|c|c|c|c|c|}
\hline \multirow{2}{*}{$\begin{array}{l}\text { Location and } \\
\text { geometry }\end{array}$} & \multirow[t]{2}{*}{ Characterisation } & \multicolumn{3}{|l|}{ Properties } & \multirow[t]{2}{*}{ Development status } & \multirow[t]{2}{*}{ Restrictions } \\
\hline & & Aquifers & $\begin{array}{l}\text { Salt formations and } \\
\text { host rocks }\end{array}$ & Existing caverns & & \\
\hline Geometry & Main Reservoir Type & Top Depth & Top Depth & $\begin{array}{l}\text { Total Cavern } \\
\text { Height }\end{array}$ & Available & $\begin{array}{l}\text { Natura } 2000 \text { and environmental } \\
\text { protected areas }\end{array}$ \\
\hline Domain & Reservoir Subtype & Total Thickness & Total Thickness & Total Area & $\begin{array}{l}\text { Current } \\
\text { Development }\end{array}$ & Urban areas or infrastructures \\
\hline Spatial Hierarchy & Lithostratigraphy & Total Area & Total Area & $\begin{array}{l}\text { Total Cavern } \\
\text { Volume }\end{array}$ & $\begin{array}{l}\text { Planned } \\
\text { Development }\end{array}$ & $\begin{array}{l}\text { Groundwater protection zones and } \\
\text { thermal springs }\end{array}$ \\
\hline $\begin{array}{c}\text { Centre point } \\
\text { latitude }\end{array}$ & Lithostratigraphy Level & Total Bulk Volume & Total Bulk Volume & $\begin{array}{l}\text { Total Mined } \\
\text { Volume }\end{array}$ & Operator Name & Other Surface Restriction \\
\hline $\begin{array}{l}\text { Centre point } \\
\text { longitude }\end{array}$ & Chronostratigraphy & Total Pore volume & Number of caverns & Number of caverns & Licence Name & Subsurface Conflict \\
\hline Country & Main Lithology & Total Porosity & & Pressure & Ownership & $\begin{array}{l}\text { Seismic risk and netotectonic } \\
\text { features }\end{array}$ \\
\hline State & Reservoir Seal Lithology & Net Porosity & & Temperature & End Year & $\begin{array}{l}\text { Alternative Use Potential }\left(\mathrm{CO}_{2}\right. \\
\text { storage, mining, geothermal) }\end{array}$ \\
\hline City & Fluid Fill & Permeability & & & Wells & \\
\hline Geological Region & & Transmissivity & & & $\begin{array}{l}\text { Storage Facility } \\
\text { Name }\end{array}$ & \\
\hline Structural Element & & $\begin{array}{l}\text { Productivity } \\
\text { Pressure } \\
\text { Temperature } \\
\text { Total Heat in place }\end{array}$ & & & & \\
\hline
\end{tabular}

regulating authorities and managing companies. A database and GIS were filled with public access information on each reservoir type such as: location of the reservoirs, geologic and stratigraphic characterisation, properties (e.g., depth, thickness or porous volume, etc.) and development status (Table 1). Two types of spatial definitions were used: "local reservoirs" which represents a concrete asset or unit that can be evaluated or deployed for storage; "regional reservoir" which represents a larger area or formation that cannot be used for storage as such but inside which there is scope for identifying site-specific (local) potential [5].

The second step involved identifying the constraints due to environmental, safety or social factors. For this purpose, the existence of environmental protected areas, groundwater protection zones and thermal springs, proximity to urban areas or major infrastructures (such as airports, highways), interference with other ongoing or planned subsurface activities (potential $\mathrm{CO}_{2}$ storage, geothermal development, salt rock mining) or seismic risk maps and neotectonic features were cross-checked against the reservoirs selected in step 1 (Table 1). 
In a third step the feasibility of deploying each large-scale energy storage technology in each prospective reservoir was assessed. The storage technologies resorting to geological reservoirs are at different stages of development and encompass a wide range of technology readiness, from conceptual designs to mature technologies (Table 5). The following confidence classes were adopted ${ }^{1}[21]$ :

- Proven: The reservoir has been developed for a given or similar technology or a confirmed development plan is present;

- Likely: Feasibility is technically considered probable. Either sitespecific assessments have been carried out or concrete plans for development are presented;

- Possibly: Feasibility is technically considered possible (based on regional quick scans, subsurface evaluations or technical assumptions). Suitability should however be confirmed by site-specific investigations.

- Unknown/Maybe: Feasibility determination is still pre-mature and suitability for the given energy storage technology is unknown/ unconfirmed. Based on generic geological assumptions there may however be scope for further investigations to assess suitability.

- Unlikely: The potential for given technology is absent or very unlikely (considering the generic geological conditions).

Steps two and three were conducted iteratively because the constraints assessed in step two may vary with storage technology and with reservoir type.

\section{Results}

About two thirds of mainland Portugal is composed by igneous and metamorphic hard-rocks from the Palaeozoic, and occasionally from the Proterozoic, affected by the Hercynian orogeny (560 - $245 \mathrm{Ma}$ ) and usually highly faulted and fractured. Sedimentary cover in these terrains is sparse and thin, mostly composed by recent alluvial and terraces, without any relevance as potential reservoirs for large scale storage. Any suitable targets in these Hercynian massifs would be the tardi-hercynian igneous intrusions.

Along the edges of that Hercynian massif, sedimentary basins were installed during the Mesozoic and Cenozoic: the Lusitanian basin, in the western Iberian margin; the Algarve basin, along the south margin of the country; and the Cenozoic Tejo/Sado Basin, that spreads along west-central Portugal. The sedimentary basins were emplaced during the opening of the Atlantic, which also promoted the intrusion of subvolcanic massifs (Sintra, Sines and Monchique massifs). Although affected by inversion movements during the Alpine cycle, the sedimentary terrains and sub-volcanic rocks are much less faulted and folded than the formations in the Hercynian massif. The Meso-Cenozoic basins are known to have several salt domes and salt formations that are priority targets for energy storage [22,23]. Porous media reservoirs were the targets in these sedimentary basins, and specifically, saline aquifers, since hydrocarbon fields are yet to be identified in Portugal.

\subsection{Salt rock reservoirs}

Salt rocks may occur underground as extensive horizontal beds with thickness ranging from a few centimetres to hundreds of meters, or as vertical structures (domes, pillars, walls) when a deep salt bed intrudes vertically into surrounding rock strata. Salt is characterized by very low permeability, which ensures a very high-quality containment for gases and air. Caverns can be easily built by dissolving the salt with injection of freshwater through vertical wells.

In Portugal salt formations are quite common in the Lusitanian Basin, where they occur both as bedded salt formations and as salt

\footnotetext{
${ }^{\mathbf{1}}$ The assessment did not incorporate legal, economic and societal aspects.
}

domes in the Lower Jurassic (Hettangian) Dagorda Formation (marls, gypsum and salt layers) (Fig. 4). The salt domes have been emplaced by halokynetic movements, where the evaporite rocks in the Dagorda Formation, due to low density and high ductility, have worked as a detachment layer, often originating listric faults, between the overlying Mesozoic cover and the underlying Upper Triassic formation [22,24].

Fig. 5a illustrates the occurrence of several salt domes, the most relevant ones being the Caldas da Rainha salt dome, extending for tens of $\mathrm{km}$ along the western border of the Bombarral sub-basin and effectively delimiting this sub-basin, the São Pedro de Moel and the Monte Real salt domes, both occurring west of the Nazaré Fault, and the Porto de MósRio Maior salt dome occurring along a NNE-SSW fault. Currently, the Monte Real salt dome is being used for storage of natural gas, with six operational caverns and three others planned.

Other salt domes in the Lusitanian basin are more localised. Amongst those, the Matacães salt dome has been mined for salt through vertical boreholes. Mining took place for several decades but operations were shut down in 2014.

Salt formations are less conspicuous in the Algarve basin, where they are associated to thick evaporitic layers in the Upper TriassicHettangian Silves Complex [23]. Some relevant anticlines are known, although only the Loulé anticline is well characterized and is currently being mined through mechanical techniques (Fig. 5c).

Hydrocarbon exploration boreholes have intersected some of the mentioned salt formations, showing thick sequences of salt interbedded with terrigenous layers, up to $1000 \mathrm{~m}$ deep in the Monte Real, S. Pedro de Moel, Pinhal Novo and S. Mamede, and shallower at Matacães, Fonte da Bica, Parceiros-Leiria and Loulé salt domes. However, for some of the salt formations and domes, such as the S. Pedro, Soure, Faro or Sesimbra domes, data about the thickness and lateral extent is virtually inexistent or inferred only from geophysical surveys.

The general criteria for selection of potential salt rock reservoirs is depicted in Table 2:

A second set of criteria relates to operational, construction, or environmental factors, and includes:

- Terrain slope $<12 \%$;

- Proximity to freshwater or groundwater sources (for solution mining) and to natural gas pipelines;

- Inexistence of environmental sensitive areas and groundwater protected areas.

These criteria were applied in a Geographical Information System (GIS) environment, and those salt formations that failed any of the criteria in the entire area of surface occurrence of the salt formation, were discarded. If the salt formation fails the criteria only in part of its surface area, the salt formations was regarded as suitable.

Seventeen salt formations, either salt domes or bedded salt, were inventoried in the Hettangian "Dagorda" Formation, although several of them with relevant constraints for energy storage development in part of the surface area. In some cases data on the features of the salt formation at suitable depth is very scarce (e.g. Santa Cruz, Bolhos, Verride, Sesimbra and Faro salt domes). The known surface area of the salt domes varies considerably, from $0.8 \mathrm{~km}^{2}$ for the Santa Cruz salt dome to the almost $200 \mathrm{~km}^{2}$ of the complex diapiric valley of Caldas $\mathrm{da}$ Rainha.

The Matacães and the Campina de Cima - Loulé salt mines were also inventoried as possible reservoirs, as were the six existing and three planned salt caverns for natural gas storage, located at Carriço, in the Monte Real salt dome. Except for the Matacães mine, the other caverns are currently unavailable for storage purposes since there are ongoing or planned activities on them.

\subsection{Porous media reservoirs}

Porous media reservoirs, that is permeable sedimentary rocks (such 


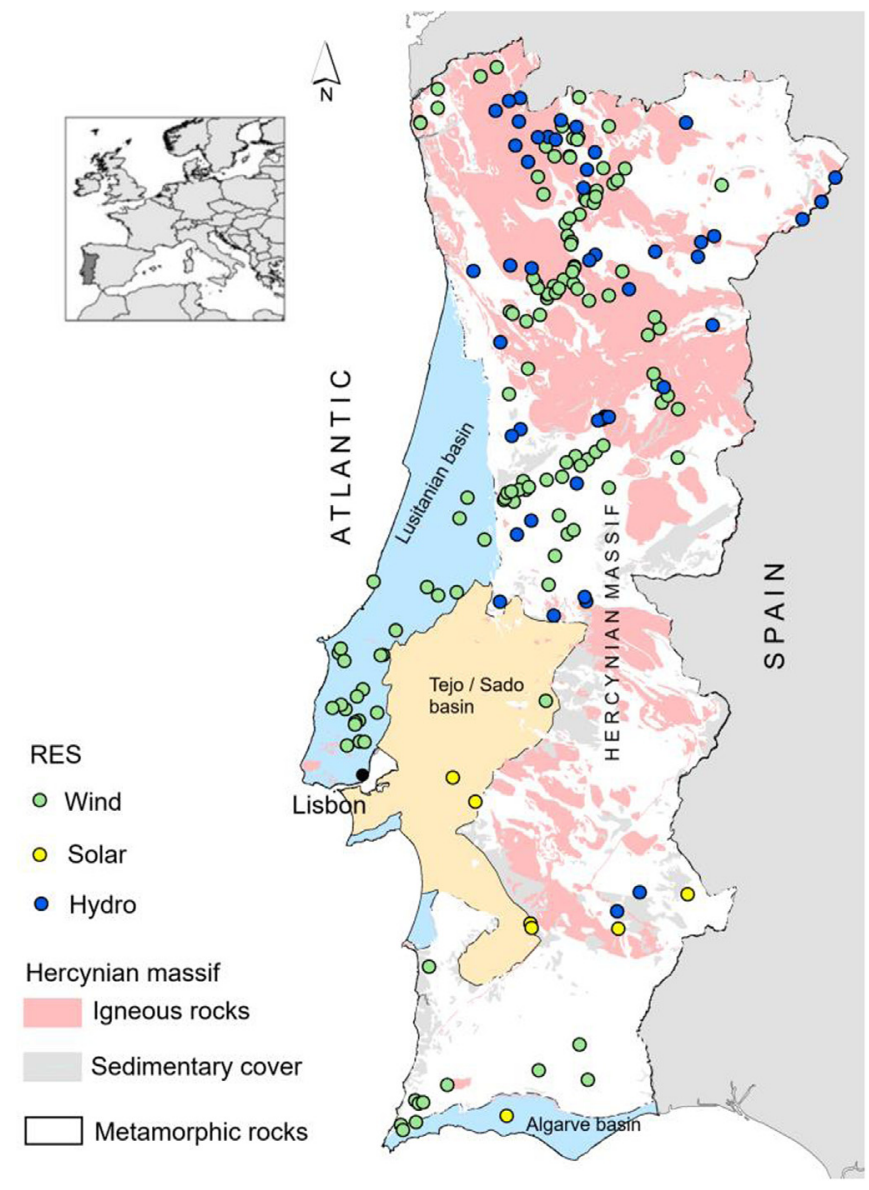

Fig. 4. Main morphotectonic units in Portugal: Lusitanian, Algarve and Tejo/ Sado sedimentary basins where the possible targets are porous media aquifers and salt formations; Hercynian massif, where the target reservoirs are the less tectonised igneous rocks. Also, shown the current (2017) locations of energy generation from renewable energy sources with a power capacity above $10 \mathrm{MW}$ (excluding the biomass and cogeneration sources). See the online version for colour code.

as sandstones, conglomerates, etc.) should preferably be saturated in high salinity groundwater, define structural or stratigraphic traps to ensure lateral containment (such as anticlines), and be overlain by an impermeable formation (the cap-rock) to avoid buoyancy and vertical migration of light fluids, namely air, methane or hydrogen [9].

The identification of the porous reservoirs was based on previous studies for assessmentof $\mathrm{CO}_{2}$ storage sites [25]. The regional-scale assessment followed a set of criteria defined in the COMET project (Table 3) and described in its deliverable D3.1 [26].

Four onshore reservoirs deemed as acceptable for $\mathrm{CO}_{2}$ storage were also considered adequate for energy storage. Further details about those aquifers can be found in Pereira et al. [25], but they are located within a relatively small area in the north sector of the Lusitanian basin and in every case the reservoir is composed by the Silves Formation sandstones and conglomerates (Upper Triassic).

Two additional reservoirs were selected based on studies conducted to identify the CAES storage potential in siliciclastic deep aquifers in the Algarve and Lusitanian basins [27,28]. They identified potential for CAES in the Lower Cretaceous siliciclastic rocks of the Torres Vedras Formation, in the north sector of the Lusitanian basin, and the Upper Jurassic sandstones of the Abadia formation in the Central sector of the same basin (Fig. 6).

\subsection{Host rocks reservoirs}

Host rocks are low permeability and low porosity rocks where energy storage can be accomplished in engineered rock caverns or in abandoned mines. The lithologies adequate for the reservoirs are igneous rocks, metamorphic rocks, shales and massive limestones, with the common requirement of not presenting relevant faulting or fracturing.

In recent years, research has focused on the possibility of using linings in the cavities (LRC - Lined Rock Caverns) to ensure containment of the fluids and allow for higher storage pressure. LRC technology widens the scope of suitable reservoirs and allows for shallower depths, at an increased economic cost. However, the possibility of using LRC was not considered in the assessment presented in this article.

The adopted methodology for reservoir assessment was crude and just based on identifying igneous massifs least subjected to fracturing and deformation stages imposed by the Hercynian orogeny. Granitoid plutons intruded during at least three stages of the Hercynian orogeny and were affected by some, if not all, of the fracturing and deformation phases of that orogeny. Those emplaced at the later (tardi to postHercynian) stages of the orogeny show less faulted and fractured conditions. Dias, Leterrier [29] have dated the plutons in the Iberian massif and identified those that correspond to tardi to post-Hercynian granites. The reservoir identification focused on those granites and considered the screening criteria presented in Table $4[5,6]$. In total, eight granite massifs were selected and included in the database. Still, it is a crude regional analysis, requiring local-scale studies.

The host rocks not affected by the hercynian orogeny, emplaced during the initial stages of opening of the Atlantic, are more likely to be suitable for energy storage in engineered caverns. There are only three such igneous rock massifs in onshore Portugal, the Sintra, Sines and Monchique sub-volcanic massifs. The Sintra massif was discarded since it coincides with one of the most important environmental protected areas in the country. The other two massifs show more favourable locations. In fact, there is already an engineered cavern built in the Sines massif for storage of Liquified Petroleum Gas (LPG), operating for several years, proving that the massif presents adequate conditions for storage of energy carriers.

Twelve host rocks formations were selected as prospective underground reservoirs, including the LPG cavern in the Sines massif, which may present an opportunity for energy storage, should its current use be discontinued (Fig. 7). Apart from the LPG cavern and the Sines and Monchique massifs, which are known to be poorly fractured and faulted, the level of confidence for all other granitoid massifs is low, and its inclusion in the list of potential suitable sites should be regarded just as indications of areas for further studies, notably on the degree of faulting and fracturing.

\subsection{Feasibility of storage technologies}

The geological reservoirs (Fig. 8a) selected in step 2 of the methodology were further screened against the criteria required for implementation of each of the energy storage technologies, taking into account the maturity of the technologies (Table 5). Each of the reservoirs were classified as Proven, Likely, Possibly, Unknown/maybe or Unsuitable for CAES, UPHS, UTES and UGS technologies as shown in Fig. 7.

With respect to the technologies involving the storage of inflammable gases (UGS, which involves storage of methane or hydrogen), or of air at high pressure, evaluating the adequacy of the technology involved a further set of criteria (based on the portuguese safety regulations for natural gas storage [30]:

- Distance to airports or military facilities $>20 \mathrm{~km}$.

- Distance to roadways or railways $>100 \mathrm{~m}$.

- Distance to populated areas $>200 \mathrm{~m}$. 


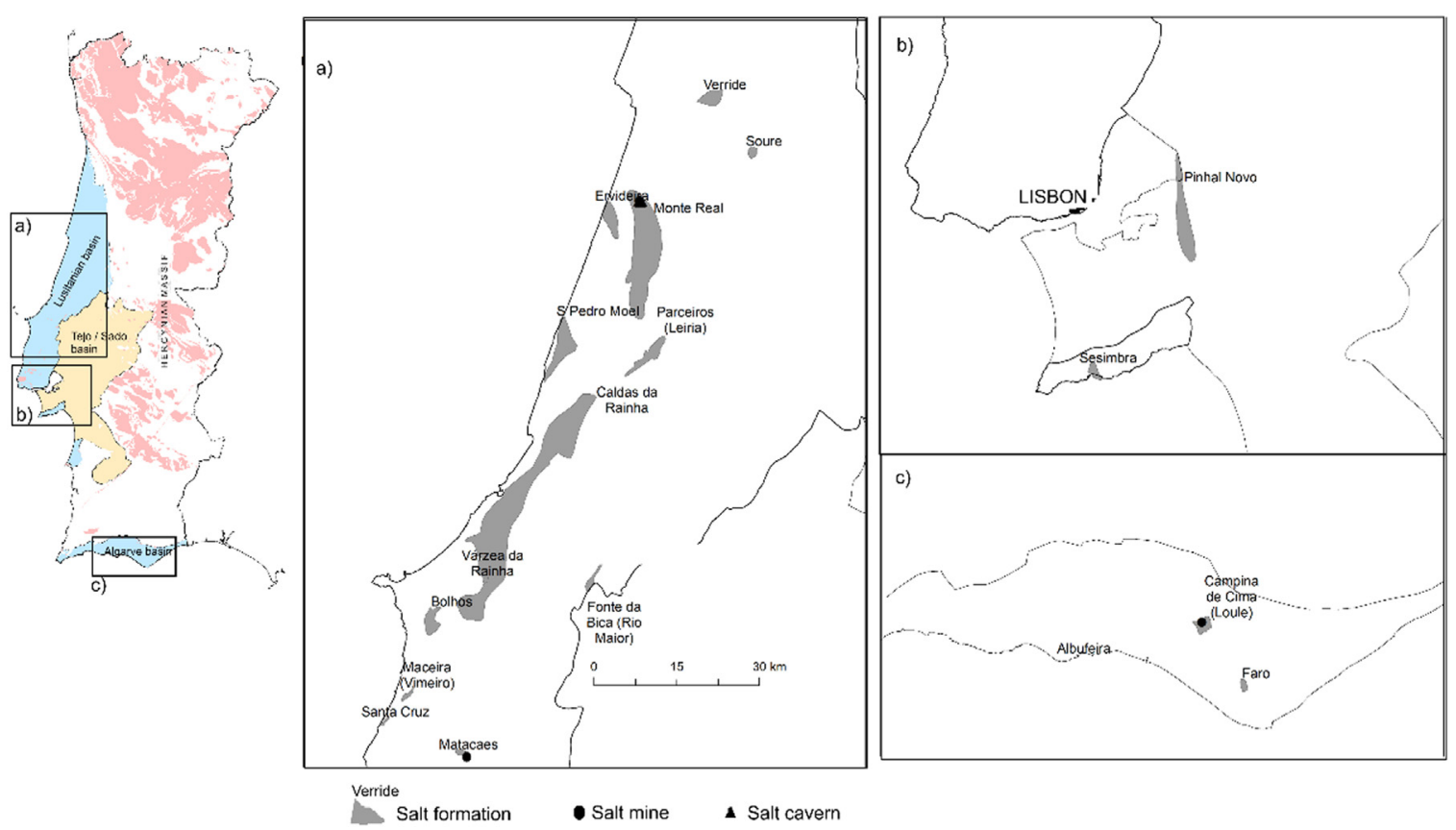

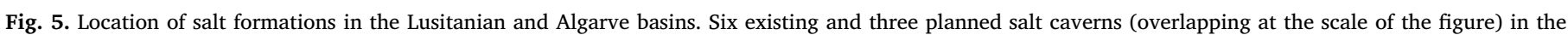
Monte Real salt dome and two salt mines are also shown.

\section{Table 2}

Screening criteria for selection of salt formations for energy storage in solutionmined caverns. Based on $[5,6]$.

\begin{tabular}{ll}
\hline Criteria & Requirements \\
\hline Geology Rock Type & Salt formations \\
Structure & Salt Domes or Bedded Salt \\
Composition & $95 \%$ of Halite \\
Caprock & Anhydrite, Gypsum, Limestone \\
Depth & $200-2000 \mathrm{~m}$ \\
Height of cavern (H) & Typical values around $300 \mathrm{~m}$ \\
Diameter of cavern (D) & Typical values around $70 \mathrm{~m}$ \\
Maximum Salt temperature & $80^{\circ} \mathrm{C}$ \\
Volume of Storage & $300,000-750,000 \mathrm{~m}^{3}$ (Salt domes); $100,000 \mathrm{~m}^{3}$ \\
& $($ Bedded Salt)
\end{tabular}

- Nonexistence of known active faults or high seismic risk.

The technologies with the largest potential for application in the geological reservoirs identified in mainland Portugal are CAES and UGS (Fig. 7). For CAES the assessment identified three Likely reservoirs (two salt formations and one abandoned salt mine), multiple Possibly reservoirs (the nine existing or planned salt caverns, most of the salt formations and all six saline aquifers). Almost every potential igneous rock reservoir was regarded as Unknown/maybe, while the Vila Pouca de Aguiar pluton, crossed by an important active fault and the $L P G$ Sines cavern, due to its shallow depth, were considered unsuitable for CAES purposes.

The salt caverns currently used in Portugal for storing natural gas reserves in salt caverns are considered Proven reservoirs for UGS, as is the Monte Real salt dome where those caverns were built. The three planned caverns for natural gas storage were labelled as Likely reservoirs. Nine salt formations were deemed as Possibly. All aquifer and host rock reservoirs were considered Unsuitable or Unknown/maybe. The

Table 3

Screening criteria for selection of deep saline aquifers for energy storage.

\begin{tabular}{|c|c|}
\hline \multicolumn{2}{|l|}{ Storage capacity } \\
\hline Porosity & $\begin{array}{l}6-15 \% \text { porosity, storages will be taken in account depending on other parameters. More than } 15 \% \text { porosity, storages will be } \\
\text { considered. }\end{array}$ \\
\hline Trap type & Aquifer traps and regional aquifers. \\
\hline Depth of reservoir & $\begin{array}{l}\text { Structures and formations whose top is placed at } 500 \mathrm{~m} \text { or higher depths. Depths higher than } 2000 \mathrm{~m} \text { due to porosity decrease } \\
\text { and costs increase with depth. }\end{array}$ \\
\hline \multicolumn{2}{|r|}{ (1) - } \\
\hline Trap type & Closed traps/closed aquifers to be favoured over open aquifers. \\
\hline Permeability & $\begin{array}{l}\text { Permeability preferably above } 200 \mathrm{mD} \text { for a specific reservoir to provide sufficient injectivity. Lower permeability considered } \\
\text { depending on other parameters. }\end{array}$ \\
\hline $\begin{array}{l}\text { Rock mechanics, diffusivity, evolution of } \\
\text { piezometry. }\end{array}$ & $\begin{array}{l}\text { Maximum pressure increases related to the geo-mechanical characteristics of the aquifer, and its propagation into the aquifer } \\
\text { governed by diffusivity. Geo-mechanical and diffusivity parameters should be taken into account whenever information is } \\
\text { available. }\end{array}$ \\
\hline \multicolumn{2}{|r|}{ 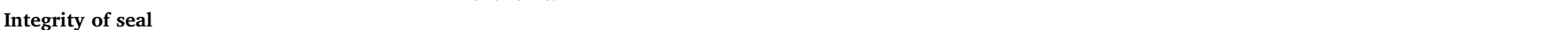 } \\
\hline Permeability & Permeability of sealing rocks low enough to prevent air flowing from the storage. Maximum permeability of $10^{-2} \mathrm{mD}$. \\
\hline Seal thickness & Sealing rock thicker than $50 \mathrm{~m}$. \\
\hline Faulting and tectonic activity & $\begin{array}{l}\text { Less faulted formations favoured. The regional tectonic activity to be considered from seismo-tectonic maps and recent seismic } \\
\text { records. Discard formations/traps crossed by active faults. }\end{array}$ \\
\hline Homogeneity of seal rocks & Homogeneous and laterally continuous formations to be favoured \\
\hline
\end{tabular}




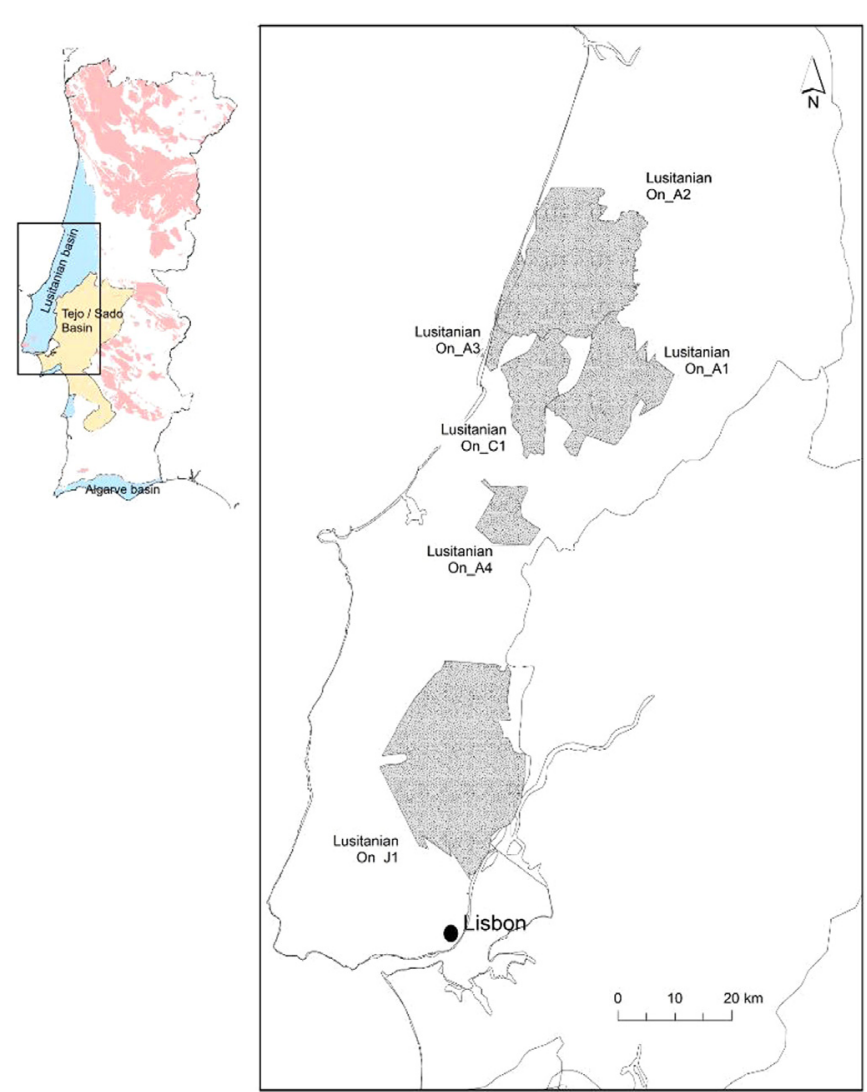

Fig. 6. Location of selected deep porous media aquifers in the Lusitanian basin.

Table 4

Screening criteria for selection of host rock reservoirs for energy storage.

\begin{tabular}{ll}
\hline Criteria & Requirements \\
\hline Geology Rock Type & $\begin{array}{l}\text { Intrusive igneous rocks, massive chemical sedimentary } \\
\text { rock, and massive nonfoliated metamorphic rocks } \\
\text { Homogeneous, isotropic rocks; no significant tectonic } \\
\text { deformations, rocks poorly faulted, fissured, jointed } \\
\text { and folded; no discontinuities. }\end{array}$ \\
& $\begin{array}{l}70-200 \mathrm{~m} \text { or depths where the hydrostatic pressure of } \\
\text { ground water equals or slightly exceeds the pressure of } \\
\text { the stored product }\end{array}$ \\
Depth & $\begin{array}{l}\text { Low Porosity } \\
\text { Low Permeability }\end{array}$ \\
Porosity & $<10^{-8} \mathrm{~m} / \mathrm{s}$ for water \\
Permeability & From 4 to $80^{\circ} \mathrm{C}$ \\
Thdraulic Conductivity & 30 years or longer \\
Lifetime of Storage & \\
Caverns &
\end{tabular}

same feasibility classification was adopted for storage of methane and hydrogen, although it is acknowledged that the much smaller hydrogen molecule is more prone to diffusion and is more demanding in terms of sealing capacity of the storage complex.

UPHS and UTES seem to be of less obvious interest, the former because the suitable reservoirs are restricted to caverns to be built in igneous rocks, which are mainly situated in locations (northern part of the country) where topography is also favourable to implement the less expensive PHS with surface reservoirs. Suitable reservoirs for UTES are restricted to aquifers, although due the scarcity of information those were classified as Unknown/maybe possibilities. Nevertheless, and given the mild climatic conditions of the country, it is not obvious the implementation of large-scale UTES, even though small scale projects may be of interest.
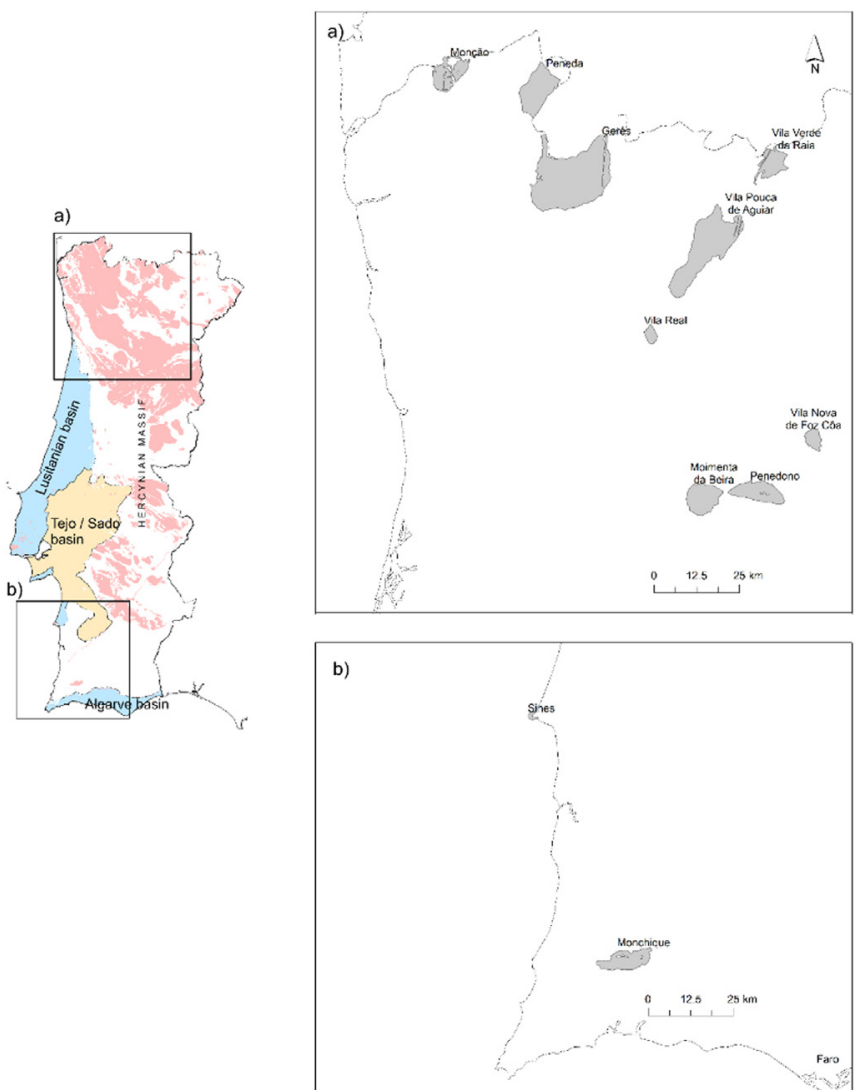

Fig. 7. Location of igneous host-rock reservoirs. The Sines sub-volcanic massif hosts a cavern for LPG storage purposes.

\section{Discussion}

In Portugal the consumption of electricity from the public grid totalled 49.3 TWh in 2016, a decrease of $5.6 \%$ below the historical maximum recorded in 2010. Peak power demand reached $8141 \mathrm{MW}$ in 17 February, $480 \mathrm{MW}$ below the previous year and around $1260 \mathrm{MW}$ lower than the all-time high in 2010 [31].

Fossil fuels still play an important role in the energy system, particularly coal, which was responsible for $21 \%$ of power output in 2016 [31], but wind and hydro power have gained considerable importance as Energy Sources, even though the share of hydropower is highly dependent on the hydrological conditions [32]. In 2016, Renewable Energy Sources (RES) accounted for $57 \%$ of consumption (Fig. 9), compared to $47 \%$ in the previous year. The meteorologic conditions also affect the electricity market. In a wet hydrological year, domestic production can cover around $95 \%$ of electricity consumption, while in dry years the "net" imports can reach $20 \%$ of demand (e.g. 2012).

Non-dispatchable generation in 2016 reached 21.5 TWh, with the load diagram on the day of peak annual demand (17/2/2016) showing a variation from $4814 \mathrm{MW}$ in the void period, to around $8141 \mathrm{MW}$ in peak periods [31]. This fluctuation was met by natural gas and an increase in imports, since wind and hydro power production was unavailable or insufficient, illustrating the relevance that energy storage can play for the country. Currently, energy storage coupled with RES is restricted to PHS, which accounted for around 1.1 TWh supply in 2015, with the energy consumption from pumps reaching some 1.5 TWh.

The National Renewable Energy Action Plan (NREAP) comprises sectorial annual targets up to 2020 , namely: $50 \%$ of renewable electricity, $34 \%$ of renewable energy consumption in heating and cooling and $12 \%$ share of renewable energy in transport, corresponding to a total consumption of gross final energy from RES of $32 \%$ in a reference scenario [32]. Considering the high national RES potential and the 


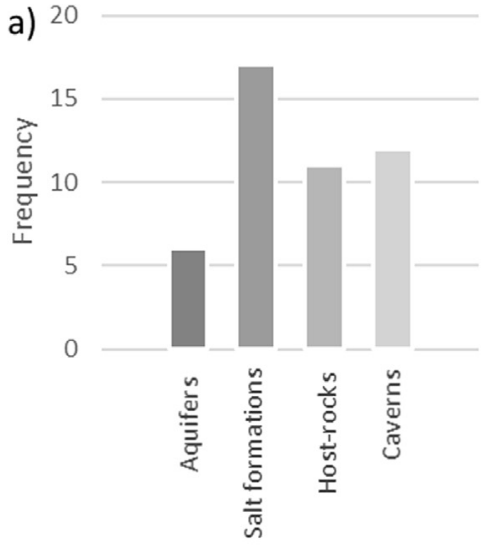

Reservoir types
20

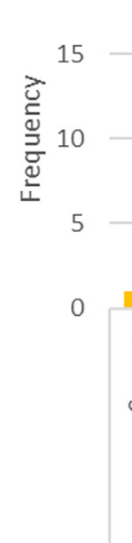

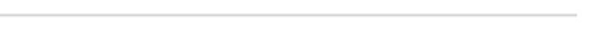

b)

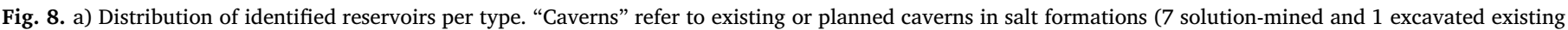

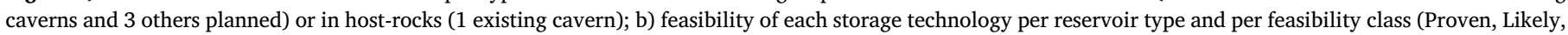

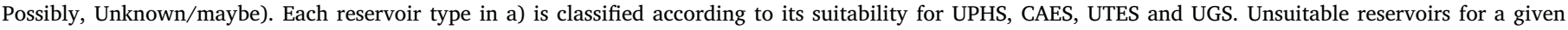
technology can be inferred by comparing charts a) and b). See online version for colour code.

ambitious agenda of the current public policy, it is expected that Portugal becomes a EU leader in renewable electricity exports with the increase of electricity interconnections between Iberia and other European countries.

Fig. 10a depicts the location and type of the potential geological reservoirs for large-scale energy storage identified, although with varying degrees of knowledge and uncertainty, and the location of the existing RES (wind, solar, small hydro) power generation facilities. There is an excellent overlap between the location of wind facilities and the selected reservoirs in salt formations and porous media aquifers in the western part of the country. This overlapping also occurs with the host-rocks reservoirs located in the south of the country, namely in the Sines and Monchique massifs, and with some of the granitoids massifs selected in the northern part of thecoutnry.

Solar sources are not favourably located with respect to the storage opportunities, being mostly located in the south of the country, in Alentejo, where the geology is dominated by metamorphic and some igneous rocks, invariably highly tectonised.

Hydropower sources predominate in the north and central Portugal. There is some coincidence of locations with reservoirs in host rocks in the north of country, but in region the topographic conditions are adequate for PHS, with no need to resort to an underground reservoir.Motivation for combining energy storage in geological formations with hydropower sources would have to come from environmental aspects, rather than from the absence of topographic conditions.

The existing and planned caverns, either excavated or built by solution-mined, and designed to be used for natural gas or LPG storage, are not distant from wind farms. Should their current or planned use be discontinued, those caverns could provide interesting spots for detailed studies aiming to combine surplus electricity production from the wind farms with CAES or UGS opportunities.

Fig. 10b overlaps the location of the selected geological reservoirs, the very high voltage electricity distribution grid and the natural gas pipelines. Notice that the standard configuration of CAES (diabatic CAES) requires air heating in the discharge phase and injection of the gas (methane, hydrogen) resulting from P2G requires proximity to a gas transport network.

Once again, the salt and aquifer reservoirs in western Portugal have the most favourable location, being located near the high voltage electricity grid and the natural gas network. The existing LPG cavern in Sines and the Sines massif has a whole, are also very close to those infrastructures.

The host rock reservoirs located in the northern part of the country are, almost invariably, very distant (tens to hundreds of $\mathrm{km}$ ) from the natural gas network. The same occurs for the potential storage locations in the south of the country (the host rock reservoir in Monchique or the salt formations and salt mine in Algarve). The implementation of storage technologies requiring connection to the natural gas network would imply the need to expand that network, with obvious financial implications. That does not mean that those reservoirs cannot be used for energy storage, but merely that the applicable technologies are more restricted to either underground pumped hydro or thermal energy storage for the host-rock reservoirs and to Adiabatic CAES for the salt formations and caverns in Algarve.

Overall, it seems that the target areas for local-scale studies in Portugal should focus primarily in the western part of the country, the

Table 5

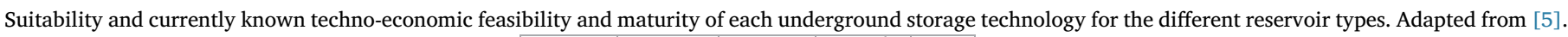

\begin{tabular}{|c|c|c|c|c|c|c|}
\hline & & CAES & UPHS & UTES & $\mathrm{CH}_{4}{ }^{1}$ & $\mathrm{H}_{2}$ \\
\hline \multirow{3}{*}{ Caverns } & Caverns in salt formations & & & & & \\
\hline & Engineered Caverns in host-rocks & & & & & \\
\hline & Abandoned Mines & & & & & \\
\hline \multirow{2}{*}{$\begin{array}{l}\text { Porous } \\
\text { media }\end{array}$} & Saline aquifers & & & & & \\
\hline & Depleted Hydrocarbons Reservoirs & & & & & \\
\hline
\end{tabular}

${ }^{1}$ assumed similar to experience with natural gas storage

Mature technology, widely implemented

Proven technology, sparsely implemented

Prospective technology, pre-commercial pilots and conceptual designs 
a)

Solar
Wind
Eydro
Biomass
Eoal
Natural Gas
Others

b)

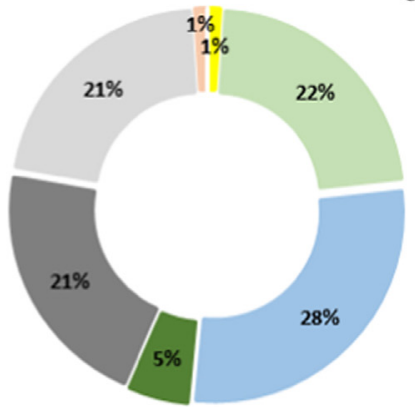

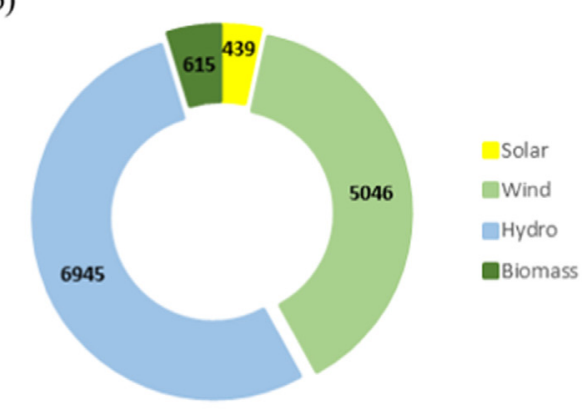

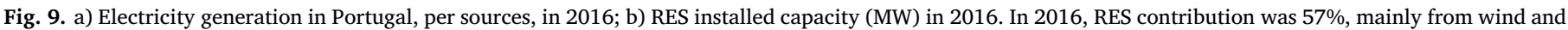
hydro. The RES installed capacity amounted to 13,046 MW. Based on data by REN [31].
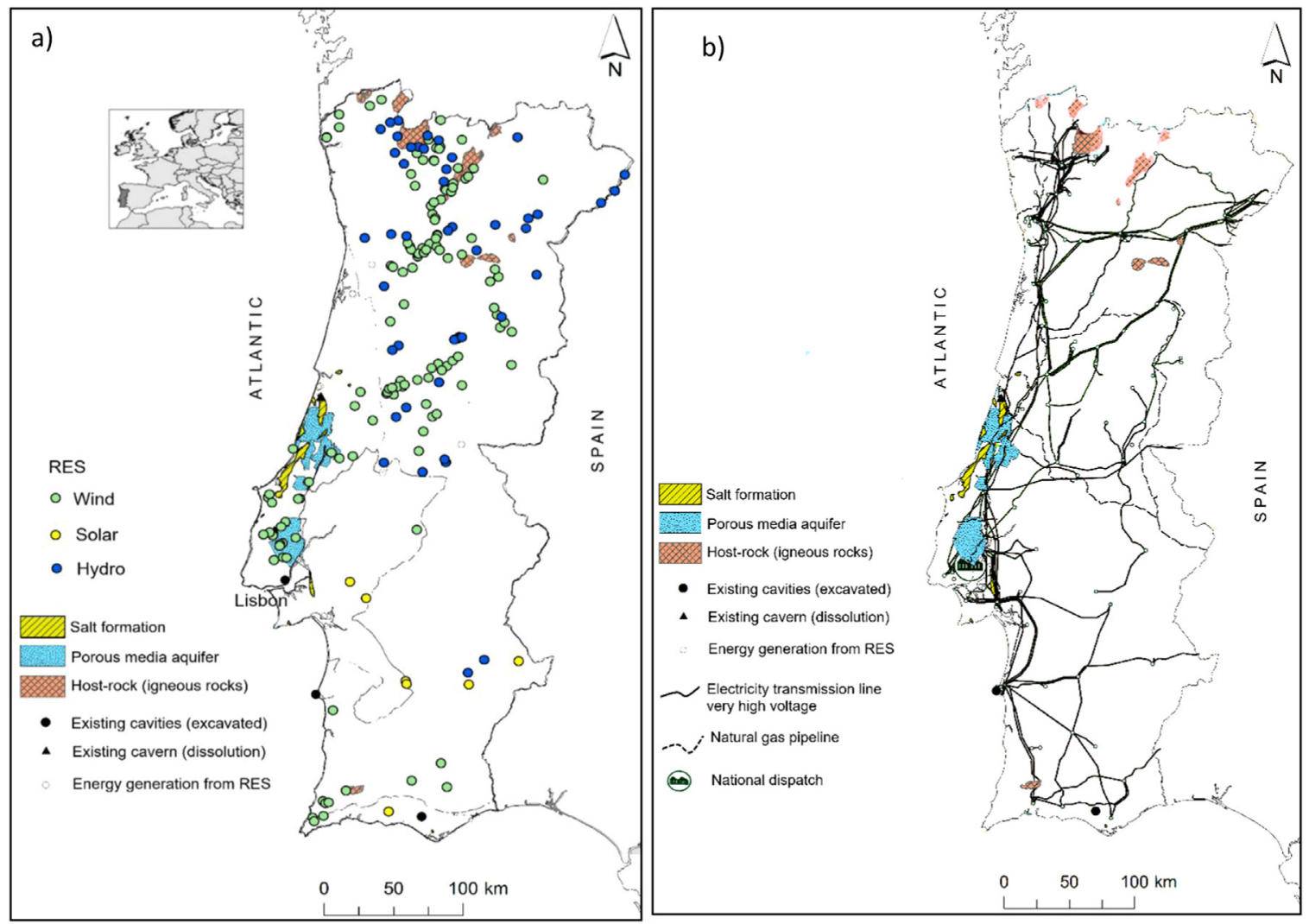

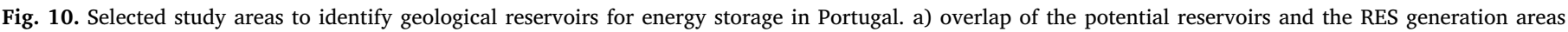

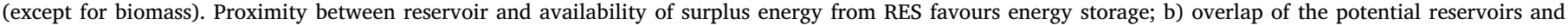

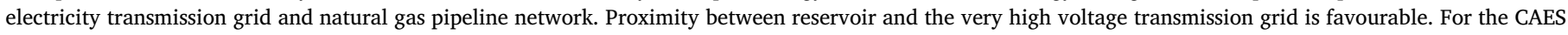
technology, supply of natural gas may be necessary during the discharge phase in Diabatic CAES to heat the expanding air.

Lusitanian basin, exploring the possibilities of using the salt formations, salt caverns and porous media aquifers to store energy surplus from the nearby wind farms or directly form the transmission grid, either in a CAES process or combined with a P2G process. The Sines massif, with proven capability to store LPG, proximity to the natural gas network, to the electricity transmission grid and to wind farms, is also an interesting location.

The host rock reservoirs located in the northern part of the country and the potential reservoirs in the Algarve are not ideally placed with respect to the required infrastructures, but local detailed studies should be considered for at least UPHS and UTES.

\section{Conclusions}

A first screening of potential sites for geological storage of energy in
Portugal was accomplished in the H2020 ESTMAP project. The analysis was based on regional scale assessments, except for the existing salt caverns and salt mines, for which local data was supplied by operators.

Amongst the prospective reservoirs, salt formations and specially the existing and planned salt caverns and two salt mines are the most interesting, since there is experience of natural gas storage in some of those caverns. Research on the adequacy for energy storage (either CAES or UGS) should focus on these two mines, aiming to characterise the current conditions and the sealing of the existing caverns. For all other potential salt formations knowledge about in situ conditions is insufficient, including in what regards the geometry of the salt domes and layers.

Saline aquifers in the Lusitanian basin, in the western coast of the country, were also identified as potential reservoirs, once again for CAES and UGS, although the information is scarcer than for salt 
caverns. As for the storage potential in host rocks, a very preliminary approach pointed towards sites that should be the subject of future works. However, unless proven by studies in other countries to have some economic advantages, storage in this reservoir type in Portugal is probably of very limited interest.

The location of the potential geological reservoirs with respect to Renewable Energy Sources, high voltage transmission lines and natural gas pipelines, indicates favourable overlapping in the western part of the country, where the existing salt caverns, one abandoned salt mine and the saline aquifers are located. The Sines industrial area, with proven capacity in host rocks, existing wind farms and well connected to power and gas networks is also an interesting area for further studies.

The identification of areas suitable for energy storage provides an economic value to the underground porous space and an incentive to deploy research programmes, including drilling and geophysical exploration in the most promising areas. Further studies should also focus on natural seismicity given the seismic risk profile of the country.

\section{Acknowledgements}

This paper was developed within the scope of the Portuguese contribution to the EU funded project ESTMAP - Energy Storage Mapping and Planning., EC Project no.: ENER/C2/2014-640/S12.698827.

The following entities are gratefully acknowledged for providing essential data and information: DGEG - Direcção Geral de Energia e Geologia, LNEG - Laboratório Nacional de Energia e Geologia, ENMC Entidade Nacional para o Mercado de Combustíveis, Solvay Portugal, CUF-Químicos Industriais S.A., and REN Armazenagem.

The identification of salt formations benefitted considerably from discussions with Eng. Alexandre Andrade, from CUF.

Three anonymous revierwes provided valuable suggestions for structuring the article.

\section{References}

[1] Barnes FS, Levine JG. Large energy storage systems handbook. Boca Raton, Fla.: CRC Press; 2011.

[2] Bauer S, Beyer C, Dethlefsen F, Dietrich P, Duttmann R, Ebert M, et al. Impacts of the use of the geological subsurface for energy storage: an investigation concept. Environ Earth Sci 2013;70:3935-43.

[3] Delmastro C, Lavagno E, Schranz L. Energy and underground. Tunn Undergr Space Technol 2016;55:96-102.

[4] ENERG. The role of the underground for massive storage of electric energy. Geo Energy; 2014. p. 4.

[5] S. van Gessel, Leynet A , Mulder A, Koorneef J , Harcouet-Menou V . ESTMAP Technical Support Document: Subsurface Data Specification. EC Project no.: ENER/ C2/2014-640/S12.698827; 2015. p. 66.

[6] Allen RD, Doherty TJ, Thoms RL. Geotechnical Factors and guidelines for Storage of Compressed Air in Salt Cavities; 1982.

[7] Budt M, Wolf D, Span R, Yan J. A review on compressed air energy storage: basic principles, past milestones and recent developments. Appl Energy 2016;170:250-68.

[8] Venkataramani G, Parankusam P, Ramalingam V, Wang J. A review on compressed air energy storage - A pathway for smart grid and polygeneration. Renew Sustain Energy Rev 2016:62:895-907.

[9] Succar S, Williams RH. Compressed air energy storage: theory, resources, and applications for wind power. Princeton, USA: Princeton Environmental Institute; 2008. p. 81.

[10] Lord A. Overview of geologic storage of natural gas with an emphasis on assessing the feasibility of storing hydrogen. Albuquerque, New Mexico, USA: Sandia National Laboratories; 2009. p. 28.

[11] Tam SW, Blomquist CA, Kartsounes GT. Underground pumped hydro storage-an overview. Energy Sources 1979;4:329-51.

[12] Nordell B. Underground Thermal Energy Storage (UTES). Innostock 2012 - 12th International Conference on Energy Storage. Lleida, Catalonia, Spain. 2012. p. 10

[13] Gao Q, Li M, Yu M, Spitler JD, Yan YY. Review of development from GSHP to UTES in China and other countries. Renew Sustain Energy Rev 2009;13:1383-94.

[14] Nordell B, Grein M, Kharseh M. Large-scale Utilisation of Renewable Energy Requires Energy Storage. Int. Conf. for Renewable Energies and Sustainable Development (ICRESD_07). Tlemcen, Algeria. 2007. p. 6

[15] Nordell B. Large-scale Thermal Energy Storage. WinterCities'2000, Energy and Environment. Luleå, Sweden. 2000. p. 10.

[16] Verhoeven R, Willems E, Harcouët-Menou V, De Boever E, Hiddes L, Veld POt, et al Minewater 2.0 project in Heerlen the Netherlands: transformation of a geothermal mine water pilot project into a full scale hybrid sustainable energy infrastructure for heating and cooling. Energy Proc 2014;46:58-67.

[17] EASE. EASE study on energy storage demand. Brussels: European Energy Storage Association; 2018. p. 13.

[18] International Energy Agency. Technology Roadmap Energy Storage. In: IEA, editor. Paris, france: IEA; 2014. p. 64

[19] European Union. The future role and challenges of Energy Storage (DG ENER Working Paper). Brussels 2013. p. 36.

[20] European Union. Technical information on Projects of Common Interest. Brussels: European Commission; 2018. p. 62.

[21] Bauer S, Dahmke A, Kolditz O. Subsurface energy storage: geological storage of renewable energy_capacities, induced effects and implications. Environ. Earth Sci. $2017 ; 76$.

[22] Kullberg JC, Rocha R, Soares AF, Rey J, Terrinha P, Callapez P, et al. A bacia lusitaniana: estratigrafia, paleogeografia e tectónica. In: Dias R, Araújo A, Terrinha P, Kullberg JC, editors. Geologia de Portugal no Contexto da Ibéria Universidade de Évora. Évora: Universidade de Évora; 2006. p. 317-468. [418 pp].

[23] Terrinha P, Rocha R, Rey J, Cachão M, Moura D, Roque C, et al. A Bacia Algarvia: estratigrafia, paleogeografia e tectónica. In: Dias R, Araújo A, Terrinha P, Kullber JC, editors. Geologia de Portugal no Contexto da Ibéria Universidade de Évora. Évora: Universidade de Évora; 2006. p. 247-316. [418 pp].

[24] Kullberg JC. Evolução tectónica mesozóica da Bacia Lusitaniana. Lisbon: Universidade Nova de Lisboa; 2000.

[25] Pereira N, Carneiro JF, Araújo A, Bezzeghoud M, Borges J. Seismic and structural geology constraints to the selection of $\mathrm{CO}_{2}$ storage sites-The case of the onshore Lusitanian basin, Portugal. J Appl Geophys 2014;102:21-38.

[26] Martínez R, Suárez I, Le Nindre YM. Site selection criteria. COMET Deliv 2010;3.1. [p. $10 \mathrm{pp}$.

[27] Susano F. Características hidrogeológicas de meios porosos para armazenamento de energia sob a forma de ar comprimido. Évora: Universidade de Évora; 2015.

[28] Cavaco LE. Definição de reservatórios geológicos para armazenamento de energia em ar comprimido e sinergias com produção de energia. Évora: Universidade de Évora; 2013.

[29] Dias G, Leterrier J, Mendes A, Simões PP, Bertrand JM. U-Pb zircon and monazite geochronology of post-collisional Hercynian granitoids from the Central Iberian Zone (Northern Portugal). Lithos 1988;45:349-69.

[30] Costa LR. Potencial de Armazenamento Subterrâneo de Gás Natural do Território Nacional. In: DGEG, editor. Lisbon, Portugal: Direção Geral de Energia e Geologia - DGEG; 2009.

[31] REN. Technical data 2016. Lisbon, Portugal: REN - Redes Energéticas Nacionais; 2017. p. 36.

[32] Seixas J, Fortes P, Dias L, Carneiro J, Boavida D, Aguiar R, et al. $\mathrm{CO}_{2}$ capture and storage in Portugal: a bridge to a low carbon economy. LIsbon, Portugal: FCT-UNL; 2015.

[33] Aneke M, Wang M. Energy storage technologies and real life applications - A state of the art review. Appl Energy 2016;179:350-77.

[34] Martin GD. Aquifer Underground Pumped Hydroelectric Energy Storage [PhD Thesis]. University of Colorado; 2007. 